\title{
FACTORS INFLUENCING CONSUMER ATTITUDE AND PERCEPTION TOWARDS ONLINE TO OFFLINE (O2O) FOOD DELIVERY BUSINESS IN A TIER 3 CITY OF INDIA
}

\author{
Aarti Rishi ${ }^{1}$, Chidanand Patil ${ }^{2}$ and Venu Prasad H D ${ }^{3}$
}

\begin{abstract}
The growth in technology coupled with low-cost mobile data plans attracts many people to access the Internet, which has resulted in a spike in Online to Offline (O2O) business in India including Online Food Delivery (OFD) platforms. In the present global COVID-19 pandemic, the OFD service providers played a vital role in delivering the food to consumers and enabling the restaurants to keep operating by minimising their losses. With the increase in demand for fast and online foods, many businesses are entering into tier 3 cities in India. This study was conducted in a tier 3 city in the month of February-March 2020 to assess the consumer attitude and perception towards an OFD application, Zomato. The results indicate that the frequency of using an app, monthly expenditure of the respondent and the first five order benefits that the Zomato offers to the customers shows highly significant to the orders they place. However, most of the respondents reported digital trustworthiness, higher service charges, followed by higher prices as the challenges while ordering food. Home-cooked food with $24 \times 7$ availability were the expectations of the consumers. As the demand for online food orders increases, there is a huge scope to improve the business, if the company switches to adopt user-friendly services and provide excellent quality products at a reasonable price. Government need to ensure safety in online transactions in order to attract more people to use electronic medium for transaction. The outcome of the study would help the policy makers and OFD players to better understand the insights of consumers towards OFD system especially in a tier III cities and may take new initiative for the improvement of OFD business sector.
\end{abstract}

Key words: Online to Offline (O2O), Online food delivery, Consumer attitude, Consumer preference

${ }^{1}$ Student (Email: aartirishi995@gmail.com) \& ${ }^{2}$ Assistant Professor, Department of Applied Agriculture, Central University of Punjab, Bathinda, Punjab, India. PIN: 151001.

${ }^{3}$ Scientist (Email: venu155@gmail.com), Centre for Water Resources Development and Management, Kozhikode, Kerala, India. PIN: 673571. 
${ }^{2}$ Corresponding author email: chidusam@gmail.com 


\section{Introduction}

The rapid growth of e-commerce has given rise to many new forms of businesses like B2B (Business to Business), B2C (Business to Consumer), C2C (Consumer to Consumer) and $\mathrm{O} 2 \mathrm{O}$ (Online to Offline) ( $\mathrm{Li}$ et al, 2020). The business of $\mathrm{O} 2 \mathrm{O}$ is a marketing method based on Information and Communications Technology (ICT) whereby consumers place orders for goods or services online and receive the goods or services at an offline outlet ( $\mathrm{Li}$ et $a l$, 2020). In the past few years, the O2O Food Delivery (FD) market has flourished globally (Xu \& Huang, 2019) and O2O commerce is growing rapidly through Online Food Delivery (OFD) platforms (Li et al, 2020).

OFD can be defined as a process of distribution of food or take out from a restaurant or a local food joint through a web page or mobile app (Vinaik, 2019). Currently, 11 percent of the global population has access to FD platforms (Singh, 2019). The global market for FD stood at $€ 83$ billion or one percent of the total food market (Hirschberg et al., 2016; Dave \& Trivedi, 2019). China is the leading country in the market share of OFD followed by United States with the developing markets of India and Brazil which are showing a rapid growth of more than 9 percent (Compound Annual Growth Rate- CAGR) (Li et al, 2020). Between 2015-18, the online delivery market has embraced a growth of 25 percent and is expected to grow at a rate of 14.9 percent till 2020 (Dave \& Trivedi, 2019).

The OFD business is found to be satisfying the needs of the urban and metropolitan consumers, who are busy with their work, with no time to travel and expect the food to deliver at their doorsteps from different restaurants across the city (Ganapathy \& AbuShanab, 2020; Singh \& Verma, 2020). Different mobile food ordering applications have been widely used in the restaurant business as a creative platform for targeting consumers and supplying best quality food services (Alalwan, 2020). Indians are highly active at using mobile applications for ordering food online from various apps (Jeyakumari, 2020) and the use of apps depends on individual choice and convenience. With more than 1.2 billion population, India is at the cusp of a massive e-commerce revolution (Raman, 2018). In March 2019, food app downloads increased by 2.9 times year-on-year in India to around 46.4 million downloads (Times of India Newspaper, 2019). The revenue from the OFD system accounts for US\$9,207 million in the year 2020, with 184.3 million users and expected to increase to US\$164 billion by 2024 (www.statista.com). Currently, OFD in India is estimated 
to be worth `10.27 Billion (www.statista.com), which indicates a tremendous growth and opportunity in the coming years.

Ordering the food online has become easier, customers have more choice to access food from a wide range of restaurants to their locations with a single tap of their mobile phone (Hirschberg et al., 2016; Alalwan, 2020). Along with delivering food, the OFD business has created employment opportunities to chefs, administrative staffs in restaurants, delivery people, programmers and support industries like food packaging etc.

The number of delivery app users and their social impact has increased along with the number of smartphone users (Song et al., 2017). There were 5.2 billion smartphone connections in 2019 and it was estimated that half of the world's population will have access to mobile internet services by the end of 2020 ( $\mathrm{Li}$ et al, 2020). The low-cost mobile data packs have made India the most affordable country in accessing the internet (Mehta et al., 2019). The food apps were the second most downloaded applications for Apple iOS users and a latest Boston Consulting Group report revealed that around 60 percent of food catering customers had already embraced no less than one mobile food ordering application (Alalwan, 2020).

The factors which are responsible for the increased usage of OFD services in India are growing, these include middle class population, growing working women population, rising per capita income, increased relatively economical internet penetration, increased digital literacy, advanced mobile technology, lack of time to prepare food, availability of variety of foods, rewards and cashbacks, availability of different payment options like credit card, debit card, in-app wallet and cash on delivery, congested metropolitan cities, expansion in the pace of urbanization and the changing demographics where we have more youngsters who have more urge for eating outside food rather than home cooked food (Bajaj \& Mehendale, 2016; Bagla \& Khan, 2017; Vidwans, 2018; Sharma et al., 2018; Chakraborty, 2019; Dave \& Trivedi, 2019; Begum, 2020; Verma, 2020). Apart from this, Social media also plays an important role in the rise of OFD business and the most preferred social media platform includes Facebook followed by Instagram, wherein the companies deliver various offers and contests and try to build a connection with customers and put efforts to turn them into loyal ones (Mehta et al., 2019). 
Although there are some leading players in the OFD system in India viz., Zomato, Swiggy, Uber Eats, Foodpanda, Domino's, etc., in the present research, we focused on mainly Zomato, as its share in India is more (Fig1).

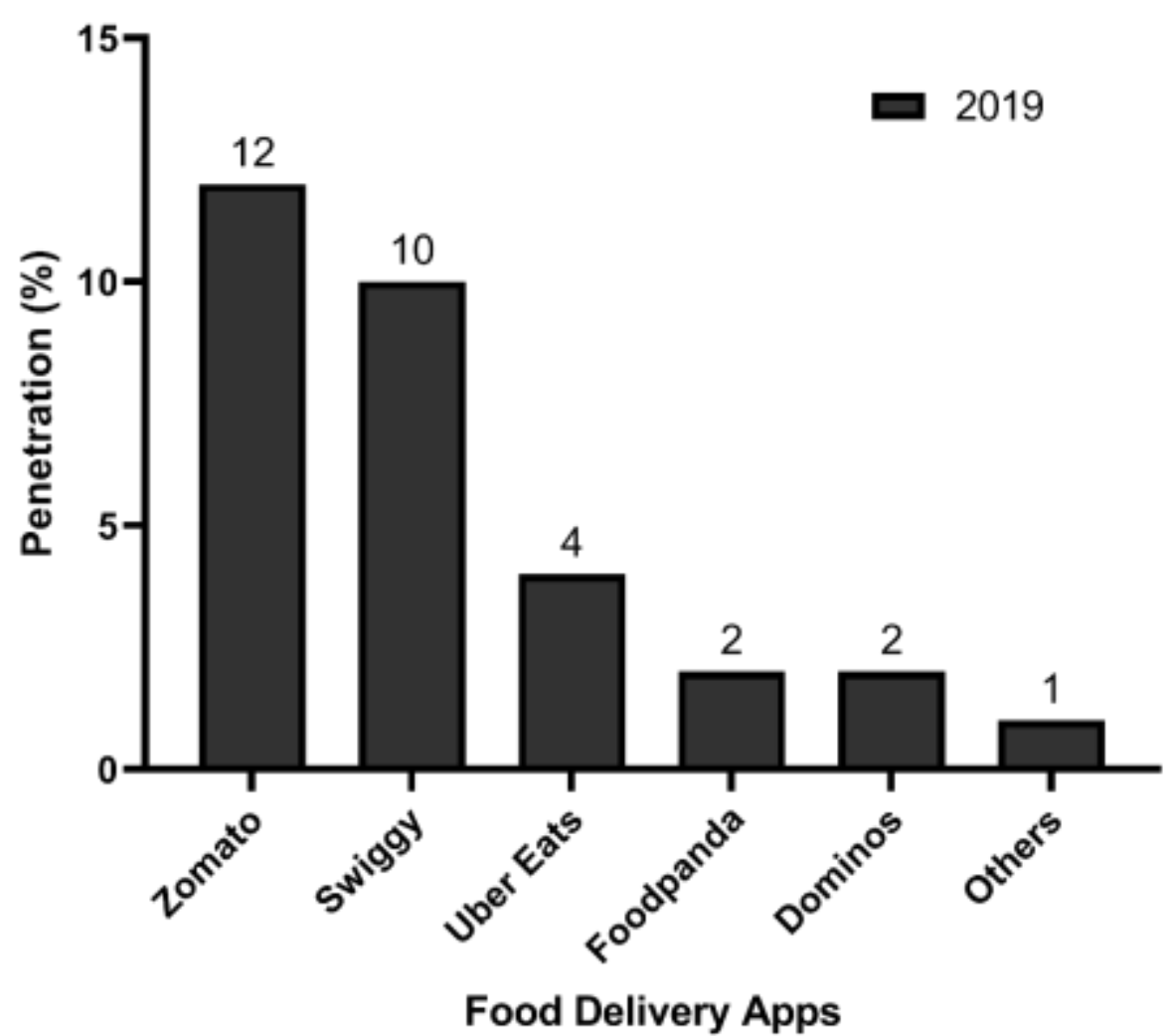

Figure 1: Food delivery Apps penetration in India Source: Parmar (2019)

\subsection{Zomato}

Zomato, an online food ordering application that has gained more popularity in a relatively short time, was founded by two Indian entrepreneurs Deepinder Goyal and Pankaj Chaddah, in the year 2008 (Sharma, 2018). Primarily set foot as a reviewer for different restaurants, later gradually expanded into the other areas of foodtech business (Raman, 2018). From the beginning, it has provided numerous benefits to the customers hence, Zomato became a familiar name, especially for food lovers (Sharma and Waheed, 2018) in India. The orders from Zomato have increased from 55 million in H1FY (First Half of Financial Year) 2019 to 214 million in H1FY 2020. The restaurant listings have rapidly expanded, the delivery partners have also increased. However, with the growing competition in the online food industry, Zomato has to update its app from time to time to include some new features. It has also started the Zomato Market services to deliver the essential grocery items at the 
consumer's doorstep. Today, it is present in over 10,000 cities across the globe with over 1.4 million active restaurants (Chaudhary, 2019).

Only few studies are available with respect to the OFD system in tier III cities of India particularly in the state of Punjab wherein the percentage of middle-class consumers is increasing. As Zomato introduced recently in a tier- III city of Bathinda, there was a need to examine which aspects could shape customers' perception, intention, and behaviour towards the OFD app. The outcome of the study would help the policy makers and OFD players to better understand the perceptions of consumers towards OFD system especially in a tier III city like Bathinda and may take new initiative for the improvement of OFD business sector. Hence, the present study aims at understanding the consumers attitude and preference towards the OFD app Zomato in Bathinda city of Punjab.

\section{Methodology}

\section{1 Study area:}

The study conducted in purposively selected Bathinda district of Punjab, India (Fig 2). Bathinda district is in the Malwa region of Punjab. The districts encompass an area of 3,385 square kilometres (www.bathinda.nic.in). According to the area, Bathinda District is the third-largest in Punjab (after Ludhiana District and Sangrur District) (www.bathinda.nic.in). It is home to different religions, castes, cultures, and occupations. Zomato has started its service in Bathinda on $7^{\text {th }}$ December 2018 (gadgets.ndtv.com) and it is in its nascent phase. With the evolving lifestyle, however, many people can be observed ordering food online, giving the industry the potential to expand as more and more people become aware of it. Therefore, it is useful to identify the consumer attitude and perception towards food orders using the Zomato app. 


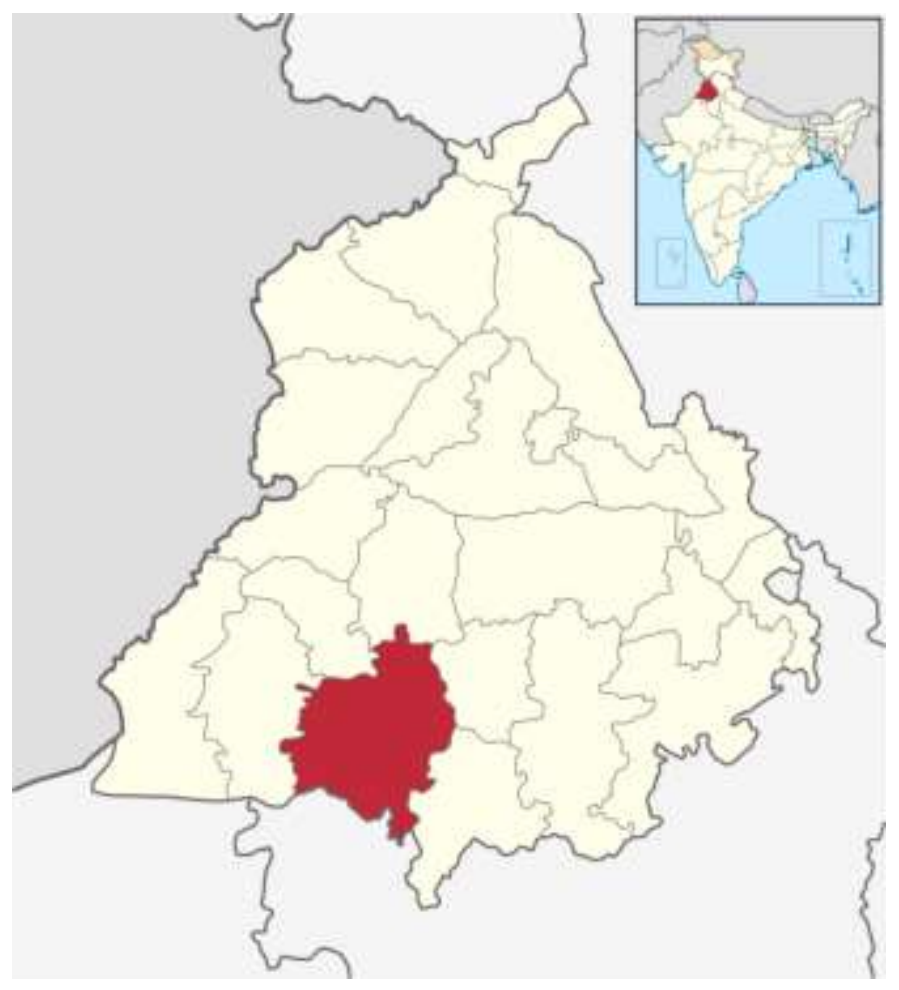

Fig 2: Map of the study area (Source: Wikimedia)

\section{2 Source of data:}

The primary data on customer socio-economic status, attitude, and perception of Zomato was collected using a questionnaire through online mode using 'Google Forms'. The target respondents were only those who used to be Zomato users. A list of those who ordered food from Zomato collected from the Zomato office of Bathinda. From this list, 200 respondents selected randomly and the respondents were pre-checked by contacting them personally before the data was collected. After making sure they had or were using the Zomato App service, a link of the 'Google Forms' was sent to the respondent's email ids/ WhatsApp numbers.

\subsection{Analysis of data:}

\subsubsection{Random Forest (RF)}

Random forest is an ensemble learning method based on classification and regression trees. Each tree trained on a bootstrap sample and optimal variables at each split identified from a random subset of all variables (Szymczak et al., 2019). The selecting criteria are different for classification and regression problems. In addition to prediction, RFs can be used to estimate variable importance measures to rank variables by predictive importance. (Szymczak et al., 
2019) In order to find out which of the independent variables influence the dependent variable i.e., Zomato orders, we performed a Random Forest algorithm using R software.

\subsubsection{Spearman's rank correlation}

Spearman's rank correlation method was used to analyse the data in order to measure the difference in the ranking attributes of the respondents (Kumar, 2016). It applied to data in the form of ranks and was estimated using the following formula:

$$
\mathbf{r s}=1-\frac{\left(6 \sum_{\mathrm{i}} \mathbf{d}_{\mathrm{i}}{ }^{2}\right)}{(\mathbf{n}-\mathbf{1}) \mathbf{n}(\mathbf{n}+\mathbf{1})}
$$

Where, $d_{i}=$ difference of the ${ }_{i}{ }^{\text {th }}$ pair and $n=$ number of differences

\section{Result and Discussion}

After analysing the data, the results of the study are presented in the following tables.

Table 1: Socio-Economic Profile of the respondents.

\begin{tabular}{|c|c|c|c|}
\hline S.No. & Particulars & Frequency & Percentage \\
\hline \multirow[t]{3}{*}{1} & \multicolumn{3}{|l|}{ Gender } \\
\hline & Male & 127 & 63.50 \\
\hline & Female & 73 & 36.50 \\
\hline \multirow[t]{5}{*}{2} & \multicolumn{3}{|l|}{ Age } \\
\hline & $15-25$ years & 107 & 53.50 \\
\hline & 25-35 years & 62 & 31.00 \\
\hline & $35-45$ years & 15 & 7.50 \\
\hline & $45-55$ years & 16 & 8.00 \\
\hline \multirow[t]{5}{*}{3} & \multicolumn{3}{|l|}{ Marital status } \\
\hline & Married & 46 & 5.50 \\
\hline & Unmarried & 151 & 75.50 \\
\hline & Divorcee & 2 & 1.00 \\
\hline & Widow & 1 & 0.50 \\
\hline \multirow[t]{5}{*}{4} & \multicolumn{3}{|c|}{ Educational qualification } \\
\hline & $10^{\text {th }}$ & 11 & 5.50 \\
\hline & $12^{\text {th }}$ & 23 & 11.50 \\
\hline & Graduation & 104 & 52.00 \\
\hline & Post-graduation & 62 & 31.00 \\
\hline
\end{tabular}




\begin{tabular}{|c|c|c|c|}
\hline \multirow[t]{2}{*}{5} & \multicolumn{3}{|l|}{ Occupation } \\
\hline & $\begin{array}{l}\text { Government sector } \\
\text { employee }\end{array}$ & 29 & 14.50 \\
\hline & $\begin{array}{l}\text { Private sector } \\
\text { employee }\end{array}$ & 52 & 26.0 \\
\hline & Self employed & 25 & 12.50 \\
\hline & Retired personnel & 5 & 2.50 \\
\hline & Housewife & 13 & 6.50 \\
\hline & Student & 70 & 35.00 \\
\hline & Unemployed & 6 & 3.0 \\
\hline \multirow[t]{3}{*}{6} & \multicolumn{3}{|l|}{ Type of family } \\
\hline & Joint & 45 & 22.50 \\
\hline & Nuclear & 155 & 77.50 \\
\hline \multirow[t]{4}{*}{7} & \multicolumn{3}{|l|}{ Size of the family } \\
\hline & 1-2 members & 6 & 3.00 \\
\hline & 2-5 members & 158 & 79.00 \\
\hline & More than 5 & 36 & 18.00 \\
\hline 8 & \multicolumn{3}{|c|}{ Monthly income of the family } \\
\hline & Less than 10000 & 17 & 8.00 \\
\hline & $10001-50000$ & 41 & 21.00 \\
\hline & $50001-100000$ & 76 & 38.00 \\
\hline & 100001 and above & 66 & 33.00 \\
\hline
\end{tabular}

Source: Author's own computation from primary data

The result indicates that 63.50 per cent of the respondents were males (Table 1). Iyer (2019) found a similar trend in which males tend to order food more frequently from food apps compared to females. The above table reveals that the majority $(53.5 \%)$ of the respondents belong to 15-25 age group, more than 75 per cent of them were single/unmarried, more than 50 per cent of them had graduated, 35 per cent of the respondents were students followed by 26 per cent of them were working in a private sector. Raina et al. (2019) reported that 45.7 per cent were students, followed by home-makers $(26.5 \%)$. Nearly 77 per cent of the respondents belong to nuclear family type (family size of 2-5 members) and 38 per cent of the respondents earn a monthly income of $>50,000$ to 1 lakh. 
A particular idea/innovation/product achieves success only when the user's attitude is in favour of that product. In this study, we examined the attitude of the respondents towards Zomato performance and the results are presented in the following table.

Table 2: Attitude of respondents towards OFD - Zomato

\begin{tabular}{|c|c|c|c|}
\hline $\begin{array}{l}\text { S. } \\
\text { No }\end{array}$ & Particulars & Frequency & Percentage \\
\hline A. & \multicolumn{3}{|c|}{ Awareness about Zomato } \\
\hline 1 & Friends & 65 & 32.50 \\
\hline 2 & Family & 13 & 6.50 \\
\hline 3 & Advertisements & 79 & 39.50 \\
\hline 4 & Internet & 42 & 21.10 \\
\hline 5 & Other & 1 & 0.50 \\
\hline B. & \multicolumn{3}{|c|}{ Time since Zomato is being used } \\
\hline 1 & Less than 6 months & 28 & 14.00 \\
\hline 2 & 6 months- 1 year & 103 & 51.50 \\
\hline 3 & $1-2$ years & 48 & 24.00 \\
\hline 4 & More than 2 years & 21 & 10.50 \\
\hline C. & \multicolumn{3}{|l|}{ Frequency of usage } \\
\hline 1 & Daily & 8 & 4.00 \\
\hline 2 & Twice a week & 39 & 19.50 \\
\hline 3 & Once a week & 46 & 23.00 \\
\hline 4 & Fortnightly & 5 & 2.50 \\
\hline 5 & Monthly & 67 & 33.50 \\
\hline 6 & Special occasions & 35 & 17.50 \\
\hline D. & \multicolumn{3}{|c|}{ Average money spent (monthly) } \\
\hline 1 & Less than Rs.250 & 23 & 11.50 \\
\hline 2 & Rs. 251- 500 & 71 & 35.50 \\
\hline 3 & Rs. 501-1000 & 69 & 34.50 \\
\hline 4 & Rs. $1001-1500$ & 16 & 8.00 \\
\hline 5 & More than Rs. 1500 & 21 & 10.50 \\
\hline E. & \multicolumn{3}{|c|}{ Preferred method for ordering food } \\
\hline
\end{tabular}




\begin{tabular}{|l|l|c|c|}
\hline 1 & Mobile apps & 197 & 98.50 \\
\hline 2 & Use of Desktop/Laptop & 3 & 1.50 \\
\hline F. & Mode of payment & 70 & 35.00 \\
\hline 1 & Cash on delivery & 23 & 11.50 \\
\hline 2 & Paytm & 45 & 22.50 \\
\hline 3 & Debit card & 41 & 20.50 \\
\hline 4 & Google pay & 11 & 5.50 \\
\hline 5 & Credit card & 1 & 0.50 \\
\hline 6 & Zomato credit & 9 & 4.50 \\
\hline 7 & Phonepe &
\end{tabular}

Source: Author's own computation from primary data

Results from the table 2 indicate that around 40 per cent of the sample respondents came to know about Zomato through advertisements followed by friends (32.5\%) and internet (21.1\%). Prabhu et al. (2018) and Kanishka (2014) reported that the source of awareness about Zomato was through friends and it was about $40 \%$ and $32 \%$, respectively.

More than half of the respondents $(51.5 \%)$ were using Zomato from past six months to a year followed by $1-2$ years (24\%), less than six months (14\%) and more than two years $(10.5 \%)$. Vinaik et al. (2019) reported that most of the respondents were using Zomato from past 1-2 years.

Around 33.5 percent of the sample respondents used Zomato to order food only on special occasions. Nearly 23 per cent of the respondents ordered food once a week from Zomato, followed by twice a week (19.5\%), monthly (17.5\%), daily (4\%) and fortnightly (2.5\%). In a study by Beliya et al. (2019) found that most of the respondents used Zomato to order food once in a week.

Around 35.5 percent of the respondents spent '250-500 on ordering food from Zomato, followed by 34.5 percent spent ` $500-1000$. In the study, Beliya et al. (2019) revealed that the average money spent on ordering food from Zomato was `500-1000. In another study by Trivedi (2018) also found similar results highlighting the average money spent on ordering food online through Zomato to be ' 500-1000. However, the results of the current study highlight that the average money spent by most of the respondents were `250-500 (35.50\%), followed by `500-1000 (34.50\%). 
As much as 98.5 per cent of the respondents ordered food using Zomato mobile app while only 1.50 per cent of the respondents preferred the Zomato website for ordering food. Maheshwari. et al. (2019) found out that the majority of the respondents (67\%) preferred mobile apps as a medium to order food online. The reason could be the ease of using the mobile application as compared to the website.

Around $35 \%$ of the respondents preferred cash on delivery, while $22.5 \%$ of respondents preferred a Debit card as their mode of payment. The respondents also used UPI mode of payment, like Google Pay (20.5\%), followed by Paytm (11.50\%) and Phonepe (4.5\%). The Credit card mode of payment was the least preferred by around 5.5 per cent of the respondents.

The inbuilt app payment, i.e., Zomato Credit was used only by 0.50 per cent of the sample respondents. In a study by Trivedi (2018) highlighted that the most preferred method of payment was cash on delivery (78.80\%) followed by Credit and Debit cards $(39.10 \%)$. Similarly, Parashar et al. (2017) found that Cash on delivery was the most preferred method by 40 per cent of the respondents. Beliya et al. (2019) revealed that Paytm was the most preferred method of payment.

Results from Fig 3 revealed that most of the respondents used Zomato for ordering snacks. These are small serves of food that are generally eaten between meals, which includes Pav bhaji, different kinds of chaats (fruit, potato, etc.), Cheese balls, Cutlets and Kababs, etc. After snacks, most of the respondents preferred ordering dinner, followed by lunch, breakfast, and supper. Iyer (2019) found that most of the respondents preferred ordering dinner (71.30\%), followed by snacks $(20.50 \%)$. Rathore et al. (2018) revealed that most of the respondents preferred to order snacks $(37.50 \%)$ from Zomato.

In terms of cuisine choice (Fig 4), the majority of the respondents preferred ordering North Indian food, followed by Chinese and Italian with North Indian. Most of the respondents preferred ordering more than one cuisine of food. Iyer (2019) found that most of the respondents preferred North Indian cuisine (35.50\%), followed by Chinese (24.20\%). 


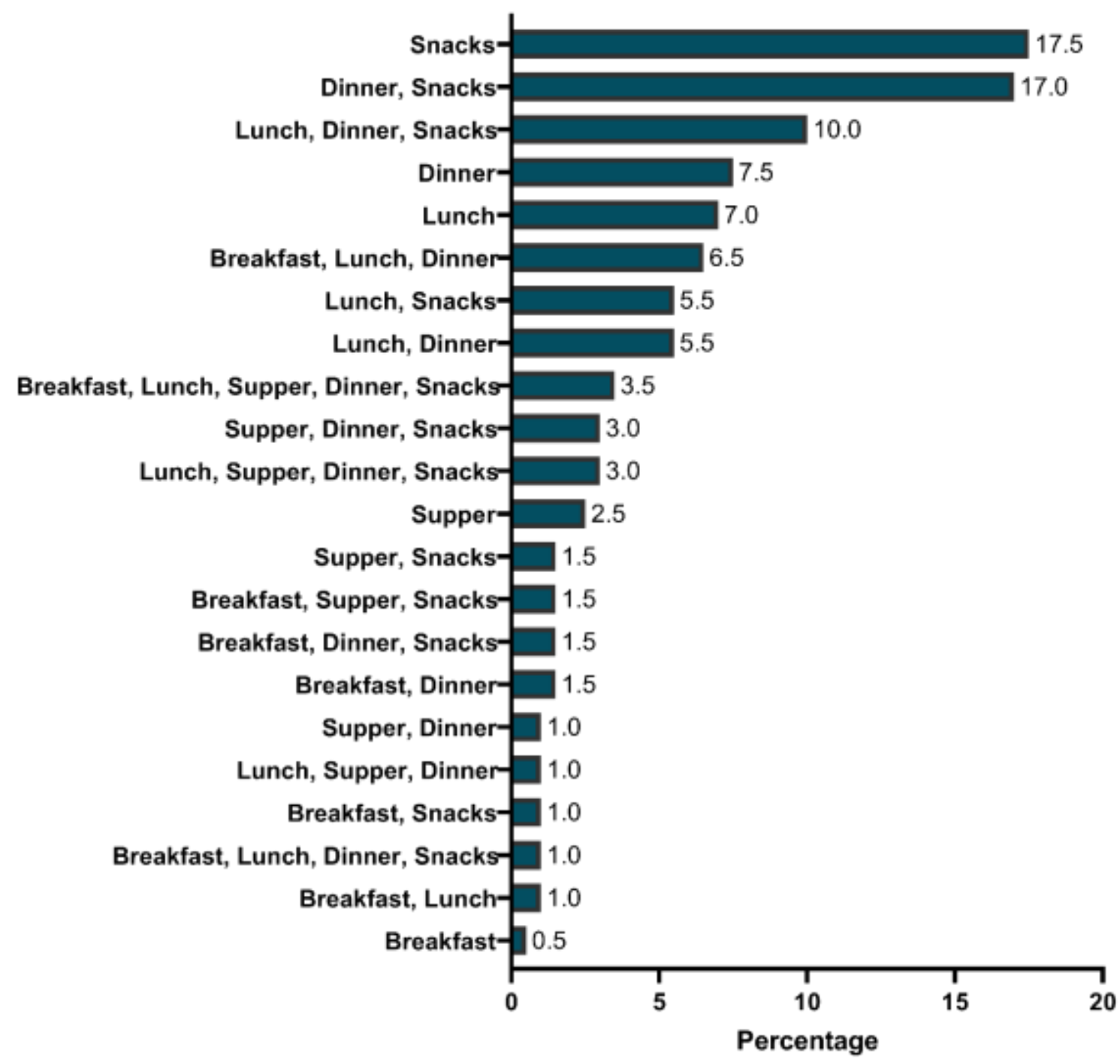

Fig 3. Respondents choice of meals (\%). 


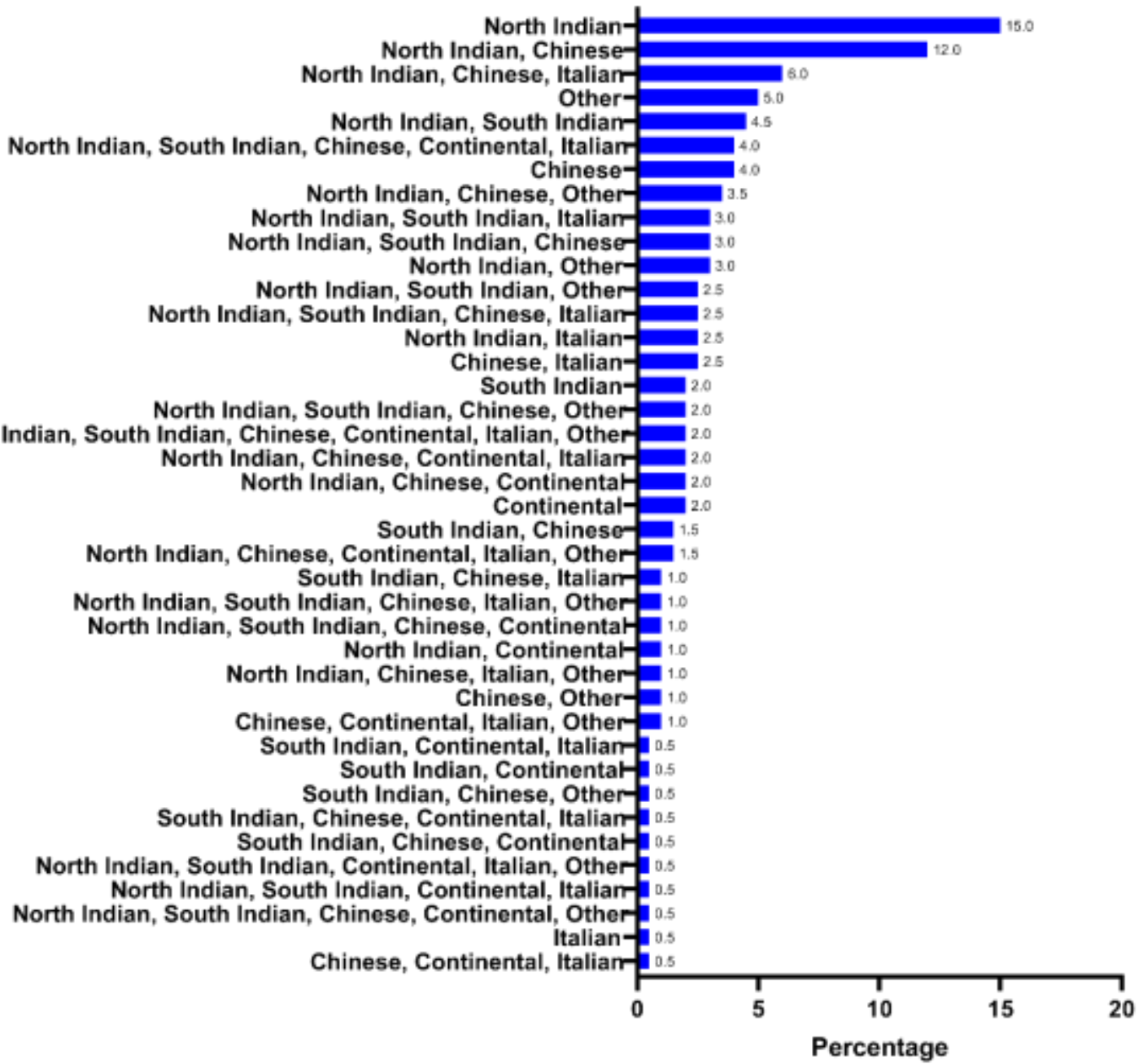

Fig 4. Respondents choice of Cuisine (\%).

Source: Author's own computation from primary data

Table 3: Attributes for ordering food from Zomato.

\begin{tabular}{|l|l|c|c|c|c|c|}
\hline S. & Particulars & \multicolumn{5}{|c|}{ Percentage } \\
\cline { 3 - 7 } No & & HS & S & N & NS & HUS \\
\hline 1 & Convenience & 19.00 & 73.50 & 6.50 & 1.00 & 0.00 \\
\hline 2 & Freshness & 11.00 & 64.00 & 23.50 & 1.50 & 0.00 \\
\hline 3 & Quality & 13.50 & 63.00 & 21.50 & 2.00 & 0.00 \\
\hline 4 & Taste & 12.50 & 67.50 & 17.50 & 2.50 & 0.00 \\
\hline 5 & Variety & 24.00 & 56.00 & 18.00 & 2.00 & 0.00 \\
\hline 6 & Price & 10.00 & 50.00 & 36.50 & 3.50 & 0.00 \\
\hline
\end{tabular}




\begin{tabular}{|l|l|c|c|c|c|c|}
\hline 7 & Transaction speed & 20.50 & 56.50 & 21.00 & 2.00 & 0.00 \\
\hline 8 & User friendly & 19.00 & 61.00 & 18.50 & 1.50 & 0.00 \\
\hline 9 & Digital payment & 27.50 & 56.00 & 15.50 & 1.00 & 0.00 \\
\hline 10 & $\begin{array}{l}\text { Reduces hurdles of preparing food at } \\
\text { home }\end{array}$ & 24.50 & 58.00 & 16.50 & 1.00 & 0.00 \\
\hline 11 & First five order benefits & 34.50 & 44.00 & 18.00 & 3.00 & 0.50 \\
\hline 12 & Referral coupon & 17.00 & 47.50 & 29.00 & 6.00 & 0.50 \\
\hline 13 & Security & 18.50 & 52.50 & 26.50 & 2.50 & 0.00 \\
\hline
\end{tabular}

- HS - Highly Satisfied, S- Satisfied, N- Neutral, NS- Not Satisfied and HUS- Highly Unsatisfied

Source: Author's own computation from primary data

The above table indicates that 34.5 per cent of the respondents were highly satisfied with the first five order benefits that the Zomato offers to its customers, followed by digital payment (27.5\%) option. In terms of satisfaction, convenience $(73.50 \%)$ to the respondents is the prominent factor influencing many to go for online Zomato orders followed by taste (67.50\%), freshness (64\%), and quality (63\%). Research studies by Vinaik et al., (2019), Prabhu et al., (2018) and Das (2019) also highlighted convenience to be the encouraging factor for ordering food online.

To find out which of these explanatory variables influence the dependent variable, we did a correlation analysis. As the dependent variable (in this case number of orders per month using Zomato app) is in the ordinal scale, it is not appropriate to use the regression to know the relationship between the independent and dependent variables. Moreover, the data is highly qualitative; the use of regression will not give an accurate result. Hence, in this study, we run a Random Forest algorithm using R software. Random forest sort variables based on its importance using INCNodePurity values by considering 500 number of trees and 11 number of variables tried at each split and the results indicated in the following figure 3.

Figure 5 explains the ranking of the relative importance of each explanatory variable on Zom ato orders. Higher the value of purity indicates higher the importance of explanatory variables . These variables explain a $25.99 \%$ variation w.r.t number of orders per month. Here Monthl y expenditure>frequency of using Zomato,> age... etc. are most influencing on Zomato order. The higher the value in the random forest, indicates higher the correlation and vice versa. 


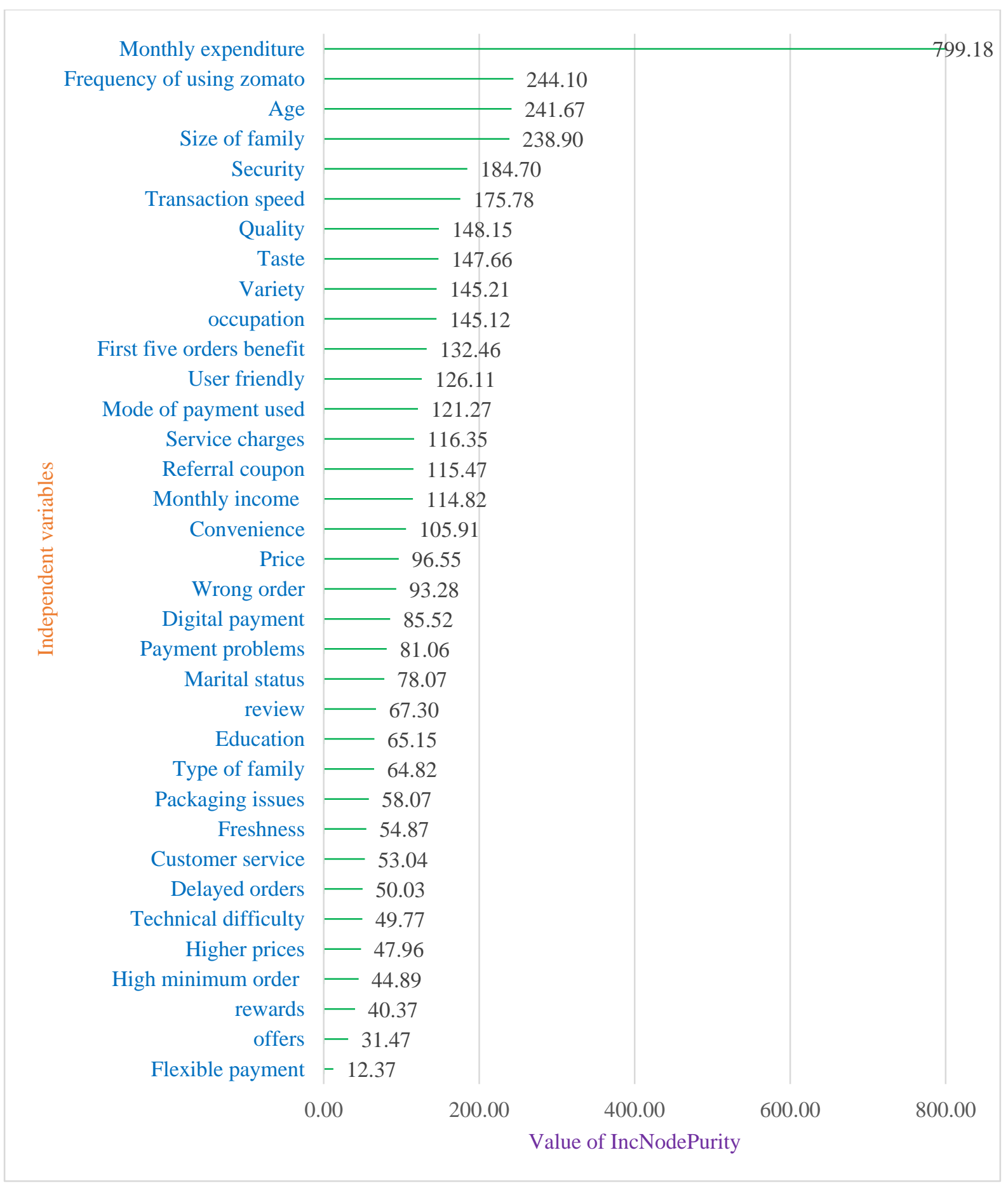

Fig 5: Relationship of independent variables w.r.t dependent variable

Source: Author's own computation from primary data

In this study the Spearman rank correlation method was used to determine the influence of ex planatory variables on the dependent variable and the results are presented in Table 4. It may be noted here that only those significant variables are shown in Table 4 below, whereas those non-significant variables are not shown. 
Table 4: Results of the Spearman Rank correlation

\begin{tabular}{|l|l|l|l|l|l|l|}
\hline \multicolumn{2}{|l|}{$\begin{array}{l}\text { Spearman Rank } \\
\text { correlation }\end{array}$} & $\begin{array}{l}\text { Frequency } \\
\text { of using } \\
\text { Zomato }\end{array}$ & $\begin{array}{l}\text { Monthly } \\
\text { expenditure }\end{array}$ & Variety & $\begin{array}{l}\text { First 5 } \\
\text { orders } \\
\text { benefit }\end{array}$ & $\begin{array}{l}\text { Monthly } \\
\text { income }\end{array}$ \\
\hline \multirow{2}{*}{$\begin{array}{l}\text { Number of } \\
\text { orders/month }\end{array}$} & $\begin{array}{l}\text { Correlation } \\
\text { Coefficient }\end{array}$ & $0.316^{* *}$ & $0.491^{* *}$ & $0.193^{* *}$ & $0.186^{* *}$ & 0.132 \\
\cline { 2 - 7 } & $\begin{array}{l}\text { Sig. (2- } \\
\text { tailed) }\end{array}$ & 0 & 0 & 0.006 & 0.008 & 0.063 \\
\hline
\end{tabular}

** Correlation is significant at the 0.05 level (2- tailed).

Source: Author's own computation from primary data

The frequency of using the Zomato app, the monthly expenditure of the respondent, variety of food available in the Zomato app and the first five order benefits that the Zomato used to offer to the customers while ordering their food shows highly significant to the dependent variable (Table 4). Moreover, the monthly income of the respondents also shown significant at $10 \%$ level. However, age (-0.011) is negatively correlated with Zomato orders, indicating that age is indifferent to the Zomato orders because it is not significant.

The reasons for a variety of food to be highly significant could be that the consumers might be preferring different options of food at different points of time as the consumers have the privilege to choose from a variety of food options that come from several restaurants registered on the portal. Moreover, consumers like to experiment with the new cuisines, thus expanding the choice of food available. It indicates that Zomato is providing a range of options in cuisine selection to meet the demands of the customers.

The first five orders benefit was also showing highly significant to the Zomato orders. It may be because Zomato is luring the consumers with its coupon code options, wherein the user could get flat $50 \%$ off or up to a maximum of ` 150 on the first five orders with no minimum amount needed to avail the offer. (This was the offer that the Zomato used to operate at the time of data collection, i.e., in the month of Feb-Mar 2020). This offer seems to be widely accepted by Zomato users and this is one of the value engineering strategies from the Zomato to attract more and more customers. 
Table 5: Satisfaction level of consumers with respect to Zomato App

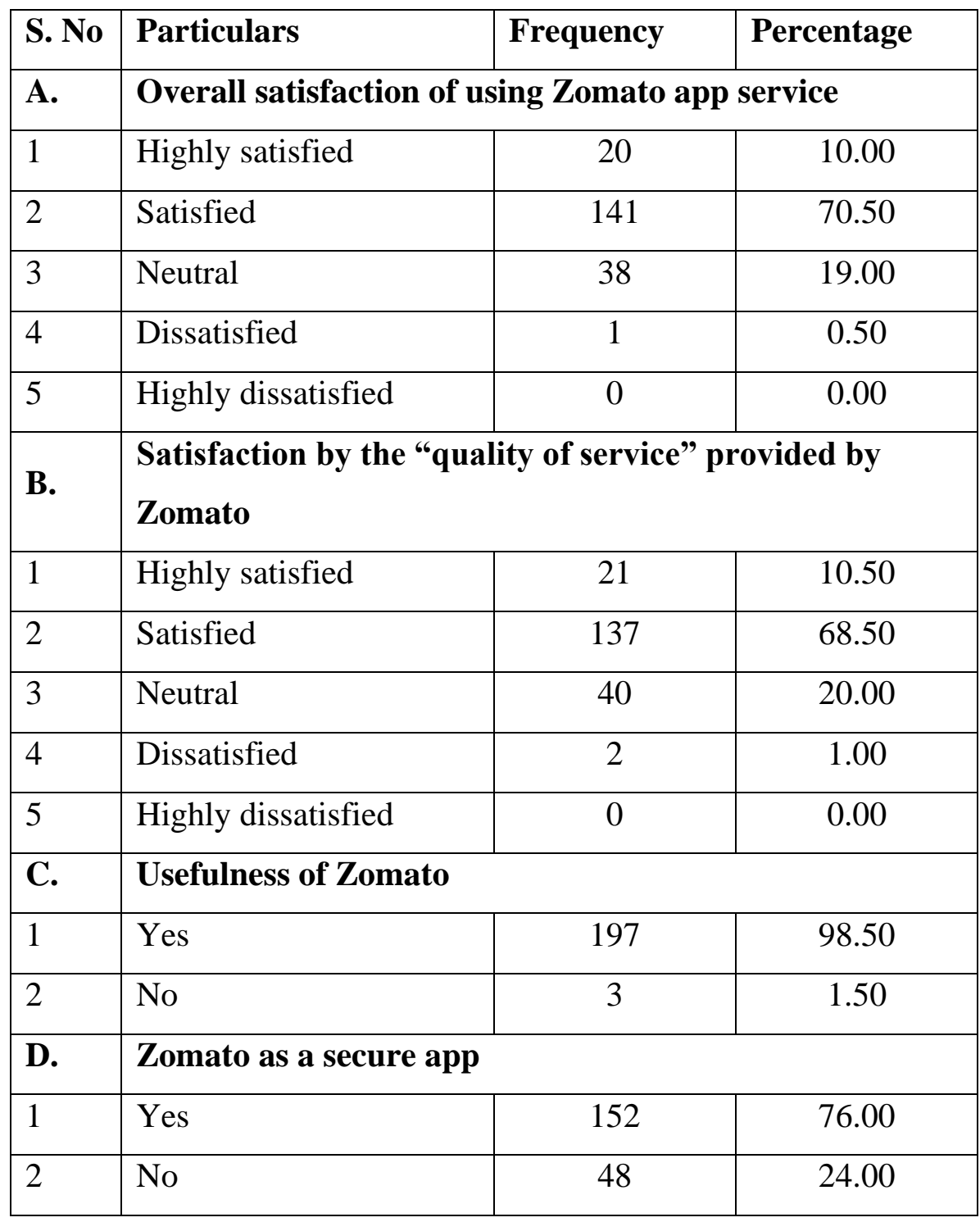

Source: Author's own computation from primary data

The results from the above table indicate that majority of the respondents $(70.5 \%)$ were satisfied with the Zomato app service. Furthermore, 68.5 per cent of them satisfied with the quality of service. As much as 98.5 per cent of the respondents found that the Zomato app service was useful. The reason for the same could be that Bathinda being a suburban area with the influx of technology and the increase of digitalization as well as the increase of market of OFD apps, people find it convenient to use these apps and thus were satisfied by the services offered. In terms of safety of the app, the majority (76\%) of the respondents found that the app was secure, whereas 24 per cent of the respondents do not find the Zomato app was secure. In a study by Kanishka (2014), highlighted that most of the respondents found Zomato app secure (80\%), whereas in another study by Vinaik et al., (2019) revealed that people don't feel safe sharing their financial and personal information over the internet. 
Another reason could be that people usually have online security issues during the transaction and most of them do not want to disclose their financial information.

Table 6: Challenges faced by the respondents while ordering food from Zomato

\begin{tabular}{|l|l|c|c|c|c|}
\hline \multirow{2}{*}{ S. } & \multirow{2}{*}{ Particular } & \multicolumn{4}{|c|}{ Responses } \\
\cline { 3 - 6 } & & Yes & Percentage & No & Percentage \\
\hline 1 & Technical difficulty & 71 & 35.50 & 129 & 64.50 \\
\hline 2 & Payment problems & 63 & 31.50 & 137 & 68.50 \\
\hline 3 & Delayed orders & 95 & 47.50 & 105 & 52.50 \\
\hline 4 & Wrong order & 47 & 23.50 & 153 & 76.50 \\
\hline 5 & Packaging issues & 95 & 47.50 & 105 & 52.50 \\
\hline 6 & Misleading reviews & 62 & 31.00 & 138 & 69.00 \\
\hline 7 & Customer service & 60 & 30.00 & 140 & 70.00 \\
\hline 8 & Service charges & 129 & 64.50 & 71 & 35.50 \\
\hline 9 & Higher prices & 96 & 48.00 & 104 & 52.00 \\
\hline 10 & High minimum order amount & 68 & 34.00 & 132 & 66.00 \\
\hline 11 & Taste & 53 & 26.50 & 147 & 73.50 \\
\hline 12 & Freshness & 63 & 31.50 & 137 & 68.50 \\
\hline 13 & Quality & 69 & 34.50 & 131 & 65.50 \\
\hline
\end{tabular}

Source: Author's own computation from primary data

Most of the respondents marked higher service charges (64.50\%) as the significant challenge faced while ordering food from Zomato, followed by higher prices (48\%), delayed orders as well as packaging issues (47.50\%) (Table 6). Technical difficulty (35.50\%), quality (34.50\%), high minimum order amount (34\%), freshness and payment problems $(31.50 \%)$, misleading reviews $(31 \%)$, customer service (30\%), taste $(26.50 \%)$ and wrong orders $(23.50 \%)$ were other difficulties faced by the respondents. In their study, Maheshwari et al. (2019) highlighted that higher service charges were one of the biggest problems faced by people while using Zomato. Prabhu et al. (2018) highlighted that most of the respondents face misleading reviews (40\%) as one of the biggest problems followed by delayed orders $(33 \%)$. In a recent study by Saxena (2019) highlighted reviews to be the biggest hindrance while using Zomato. 
Table 7: Expectations for the features to be included.

\begin{tabular}{|l|l|c|c|c|c|}
\hline S. & \multirow{2}{*}{ Particular } & \multicolumn{4}{|c|}{ Responses } \\
\cline { 3 - 6 } & & Yes & Percentage & No & Percentage \\
\hline 1 & Loyalty points & 150 & 75.00 & 50 & 25.00 \\
\hline 2 & $24 X 7$ availability & 180 & 90.00 & 20 & 10.00 \\
\hline 3 & Home-cooked food & 157 & 78.50 & 43 & 21.50 \\
\hline 4 & $\begin{array}{l}\text { Delivery for more than one customer } \\
\text { by combining orders }\end{array}$ & 97 & 48.50 & 103 & 51.50 \\
\hline 5 & Organic food & 130 & 65.00 & 70 & 35.00 \\
\hline 6 & Include small outlets & 126 & 63.00 & 74 & 37.00 \\
\hline
\end{tabular}

Source: Author's own computation from primary data

As much as 90 per cent of the respondents expected $24 \times 7$ availability of food to be incorporated, followed by home-cooked food (78.5\%), loyalty points (75\%) and organic food (65\%) (Table 7). As most of the respondents in the sample were unmarried, the preference for $24 \times 7$ availability and home-cooked food was there as it would be an aid to them if such features included. Loyalty points, however, can help retain customers as well as increase the number of new customers because that could attract a lot of potential customers who were regular users of Zomato. The study also pinpoints that around 63 per cent of the respondents expected small outlets to add to the Zomato orders. It will help in increasing the variety of food options and also helps the customers to taste the local foods.

\section{Conclusion:}

During the present time of COVID-19 (Corona Virus Disease - 19) pandemic, many businesses were affected but the restaurants somehow survived because of the services of OFD. As there is increase in demand for online food in India, this study attempts to analyse the consumer attitude and perception towards OFD app Zomato. The present study revealed that the food ordering through Zomato was reasonably accessible, with almost all the respondents were aware of it. Nearly one-third of the respondents preferred cash on delivery orders from Zomato, in spite of the fact that the Government of India is promoting online mode of payment. This may be due to the fact that the consumers experienced digital trustworthiness as the major drawback during an online transaction. Hence, the Government 
need to address the digital security issues and ensure digital safety measures so that many will choose digital payments rather than cash on delivery, which helps in reducing the chance of viral transmission through currency. The study also reveals that as the respondent's monthly income increases, the number of orders that the respondent places may also increase. If a regular monthly income option is available to the respondents in a tier III city, Zomato orders will increase. Hence, the Tier-III cities will be the future growth promoters if the Government will provide regular income-generating activities to the city dwellers.

The areas where regular income and a greater number of unmarried persons are there, in such places the OFD services will be successful provided that there should be sufficient options for the people to choose the variety of food/dishes and the company offers some loyalty and benefit points to the customers. As the demand for online food orders is increasing, there is an excellent opportunity to increase the business if the company will incorporate $24 \times 7$ orders, home-cooked food in its menu and at the same time, offers the right quality products at a reasonable price. As the business in Tier-III cities is increasing in India, these factors need to be considered to capture and expand the market either by startups through make in India or by those who already in the business of OFD.

\section{Funding:}

This research did not receive any specific grant from funding agencies in the public, commercial, or not-for-profit sectors.

\section{Author contributions statement:}

Dr. Chidanand Patil devised the main conceptual idea and design of the study. Ms. Aarti Rishi contributed in data collection and preparing the manuscript. Dr. Venu Prasad H. D. provided support in analysis of data and interpretation of results. All authors contributed to prepare and review the manuscript. 


\section{References:}

Ajbani, L. (2019). Online Food Ordering and Delivery: Perception about Quality of Services among Customers in Nashik. Journal of Engineering sciences, 10(11), 314-319.

Alalwan, A. A. (2020). Mobile food ordering apps: An empirical study of the factors affecting customer e-satisfaction and continued intention to reuse. International $\begin{array}{llll}\text { Journal of } & \text { Information }\end{array}$ https://doi.org/10.1016/j.ijinfomgt.2019.04.008

Bagla, R. K. \& Khan, J. (2017). Customers' Expectations and Satisfaction with Online Food Ordering Portals. Prabandhan: Indian Journal of Management, 10(11): 31-44. doi: 10.17010/pijom/2017/v10i11/119401

Bajaj, K. \& Mehendale, S. (2016). Food-Delivery Start-Ups: In search of the Core. Prabandhan: Indian Journal of Management, 9(10): 42-53. doi:10.17010/pijom/2016/v9i10/103073.

Begum, A. (2020). Customer's attitude and satisfaction towards online food delivery services in Tirunelveli city. Purakala, 31, 102-108.

Beliya, A., Kujur. R. \& Verma, M. (2019). Satisfaction of consumers by using online food services. International Journal of Humanities and Social Sciences (IJHSS), 8(4), 3544.

Chakraborty, D. (2019). Customer Satisfaction Towards Food Service Apps in Indian Metro $\begin{array}{llll}\text { Cities. } & \text { FIIB } & \text { Business }\end{array}$ https://doi.org/10.1177/2319714519844651

Chaudhary, D. (2019). Zomato revenue triples to $\$ 206 \mathrm{mln}$ in FY19. Available at https://www.fortuneindia.com/enterprise/zomato-revenue-triples-to-206-mln-infy19/103107\#: :text=Zomato\%20is\%20present\%20in\%20over,active\%20users\%20 on\%20its\%20platform. Accessed on $14^{\text {th }}$ January, 2020.

Das, J. (2018). Consumer perception towards 'online food ordering and delivery services': an empirical study. Journal of Management (JOM), 5(5): 155-163.

Dave, A. C. \& Trivedi, R. (2019). Predicting Youngster's Attitude towards Online Food Delivery. International Research Journal of Business Studies, 12(3): 289-299.

Dwivedi, A. \& Desai, J. (2020). Food delivery apps: a paradigm shift in the making (A study through ethical vantage point). National level conference on "Creativity and sustainability", 40(8), 549-561. 
Ganapathy, P. \& Abu-Shanab, E. A. (2020). Customer Satisfaction with Online Food Ordering Portals in Qatar. International Journal of E-Services and Mobile Applications. 12(1): 57-79, doi:10.4018/IJESMA.2020010104

Ghosh, R. \& Saha, R. (2018). A study of e-payment system on food delivery industry: a case study on Swiggy. International journal on recent trends in business and tourism, 2(3): 19-25.

Hirschberg, C., Rajko, A., Schumacher, T. \& Wrulich, M. (2016). The changing market for food delivery. Available at https://www.mckinsey.com/industries/technology-mediaand-telecommunications/our-insights/the-changing-market-for-food-delivery Accessed on $21^{\text {st }}$ August, 2020.

Iyer, B. (2019). A study of consumer behaviour towards food ordering through mobile apps. International Journal of Advance Research, Ideas and Innovations in Technology, 5(4), 360-366.

Jeyakumari, A. \& Desai, J. (2020). A study on consumer expectations and satisfaction with the online food ordering portals. Studies in Indian Places Names 40, 838-852.

Koiri, K., Mukherjee, S. \& Dutta, S. (2019). A study on determining the factors impacting consumer perception regarding the online food delivery apps in Guwahati. GIS Business, 14(6), 521-542.

Kumar, R. (2016). Studies on training needs of goat farmers in Munger district of Bihar. West Bengal University of Animal and Fishery Sciences.

Li, C., Mirosa, M. \& Bremer, P. (2020). Review of Online Food Delivery Platforms and their Impacts on Sustainability. Sustainability, 12(14), 5528, doi:10.3390/su12145528

Maheshwari, R., G, Swarnalatha. \& T, Gayathri. (2019). A study on Consumer Satisfaction towards Zomato Online Food Ordering With special reference to Coimbatore City. International Journal of Trend in Scientific Research and Development, 3(6), 683686.

Mehta, G., Iyer, T. \& Yadav, J. (2019). A study on adoption of social media by Food Ordering \& Delivering companies for successful development of Relationship Marketing. International Journal of Research and Analytical Reviews, 6(2): 53-63.

Online Food Delivery - Ireland | Statista Market Forecast. Retrieved from <https://www.statista.com/outlook/374/140/online-food-delivery/ireland > accessed on May 052020. 
Panse, C., Rastogi, S. \& Sharma. A. (2019). Understanding consumer behaviour towards Utilization of online food delivery platforms. Journal of Theoretical and Applied Information Technology, 97(16), 4353- 4364.

Parmar, B. (2019). Food Delivery Market Trends And Scope Of Mobile Applications In Food Business By 2025. Available at https://www.icoderzsolutions.com/blog/fooddelivery-market-trends-and-scope-of-mobile-applications-in-food-business-by-2025/ Accessed on $12^{\text {th }}$ January, 2020.

Prabhash, M. (2020). The consumer perception on online food delivery system among youth in Kerala. EPRA International Journal of Multidisciplinary Research, 6(2), 102-106.

Prabhu, A. \& Dongre, R. (2018). Analysis of customer attitude towards electronic food ordering. KIMI Hospitality Research Journal, 3(1), 1-6.

Raina, A., Rana, V. \& Thakur, A. (2019). Popularity of online food ordering and delivery services- a comparative study between Zomato, Swiggy and Uber eats in Ludhiana. International Journal of Management, Technology and Engineering, 10(3), 60806088.

Raman, P. (2018). Zomato: a shining armour in the foodtech sector. Journal of Information Technology Case and Application Research, 20(3-4): 130-150, DOI: $10.1080 / 15228053.2018 .1552396$

Retrieved from "In Depth Interview with Pankaj Chaddah, Founder of Zomato". The Startup Magazine. 7 November 2013.

Retrieved from "Update: Zomato breaks even in India; expands to New Zealand". MediaNama.com. 26 July 2013. Accessed on May 082020.

Saxena, A. (2019). An Analysis of Online Food Ordering Applications in India: Zomato and Swiggy. International Journal of Research in Engineering, IT and Social Sciences, 9, 13-21.

Sharma, K. \& Waheed, K. (2018). Consumption of online food app services: An exploratory study among college students in Dubai. Middle East Journal of Business, 13, 4-11.

Singh, A. \& Nair, S. (2020). Consumer perception and attitude towards online ordering. International Journal of Research in Engineering, Science and Management 3(5): 119-122.

Singh, R. K. \& Verma, H. K. (2020). Influence of Social Media Analytics on Online Food Delivery Systems. International Journal of Information System Modelling and Design, 11(3): 1-21. DOI: 10.4018/IJISMD.2020070101 
Singh, S. (2019). The Soon To Be \$200B Online Food Delivery Is Rapidly Changing The Global Food Industry. Available at https://www.forbes.com/sites/sarwantsingh/2019/09/09/the-soon-to-be-200b-onlinefood-delivery-is-rapidly-changing-the-global-food-industry/\#59187bb2b1bc Accessed on $22^{\text {nd }}$ August, 2020.

Szymczak, S., Seifert, S. \& Degenhardt, F. (2019). Evaluation of variable selection methods for random forests and omics data set. Briefings in bioinformatics, 20(2), 492-503.

The Future of Online Food Industry: Guide for Aspiring Entrepreneurs. Retrieved from $<$ https://www.fatbit.com/fab/future-online-food-industry-guide-aspiringentrepreneurs/> accessed on May 032020.

Times of India Newspaper, Downloads of food delivery apps up, touches 46.4mn. Available at

http://timesofindia.indiatimes.com/articleshow/69724198.cms?utm_source=contento finterest\&utm_medium=text\&utm_campaign=cppst Accessed on $21^{\text {st }}$ August, 2020.

Trivedi, S. (2018). Consumer perception about online sales of food in Indian consumer market. Proceedings of Academics World 99th International Conference, Paris, France, 27-29.

Vinaik, A., Goel, R., Sahai, S. \& Garg, V. (2019). The Study of Interest of Consumers in Mobile Food Ordering Apps. International Journal of Recent Technology and Engineering (IJRTE), 8(1), 3424-3429.

Verma, P. (2020). The effect of presentation, product availability and ease upon transaction reliability for online food delivery aggregator applications - moderated mediated model. Journal of Foodservice Business Research, 23(4): 285-304, DOI: $10.1080 / 15378020.2020 .1761586$

Vidwans, V. (2018). Global Food Delivery \& Takeaway Market Insights 2018-2021. Available at https://medium.com/@vyomika/global-food-delivery-takeaway-marketinsights-2018-2021-48db8bbe650e Accessed on 21st August, 2020.

Xu, X. \& Huang, Y. (2019). Restaurant information cues, Diners' expectations, and need for cognition: Experimental studies of online-to-offline mobile food ordering. Journal of Retailing and Consumer Services, 51: 231-241. 